\title{
Effect of organic acid profiles during anaerobic treatment of palm oil mill effluent on the production of polyhydroxyalkanoates by Rhodobacter sphaeroides
}

\begin{abstract}
A two-stage process for the production of polyhydroxy-alkanoates (PHA) from palm oil mill effuent (POME) is proposed. In the first stage, anaerobic treatment of POME by palm oil sludge was carried out to obtain organic acids, particularly acetic and propionic acids. The organic acids were then converted to PHA by a phototrophic bacterium, Rhodobacter sphaeroides (IFO 12203), in the second stage. During anaerobic treatment of POME by sludge, formic acid was formed when the $\mathrm{pH}$ was maintained at less than 4 . By controlling the $\mathrm{pH}$ at different values, different organic acid profiles were obtained. This study was carried out to determine the effect of formic acid on the production of PHA from acetic and propionic acids by R. sphaeroides. The results clearly indicated that the presence of formic acid substantially decreased PHA yield (g.gī 1-organic acid consumed) and PHA content in cells ( $\mathrm{g} \cdot \mathrm{g} \overline{\mathrm{I}} 1$-cell weight). In the absence of formic acid, a PHA yield of $0.50 \mathrm{~g} \cdot \mathrm{g} \overline{\mathrm{I}} 1$ and a PHA content in cells of $67 \%$ were obtained. With increasing formic acid concentration, the PHA yield and content dropped to as low as 0.21 and $18 \%$, respectively. Thus it is suggested that if POME is used for PHA production, a pH should be maintained at 7 in the anaerobic sludge treatment step, so that no formic acid is produced which would affect the maximum yield of PHA.
\end{abstract}

Keyword: Polyhydroxyalkanoates; PHA; Rhodobacter sphaeroides; Photosynthetic bacteria; Wastewater treatment; Palm oil mill effluent; Formic acid 